\title{
CALCULATION OF SEDIMENT YIELD USING THE INTERO MODEL IN THE S1-3 WATERSHED OF THE SHIRINDAREH RIVER BASIN, IRAN
}

\author{
Jovana DRAGANIĆ ${ }^{1}$, Bojana DROBNJAK ${ }^{1}$, Jovana CAMPAR ${ }^{1}$, \\ Biljana BULAJIĆ ${ }^{1}$, Vanja ZAJOVIĆ ${ }^{1}$, Morteza BEHZADFAR ${ }^{2}$, \\ Goran BAROVIĆ 3 , Velibor SPALEVIĆ ${ }^{3 *}$
}

\begin{abstract}
Soil erosion is a natural process caused generally by the force of water (running water and raindrops) or wind. The process involves not only the detachment of soil particles (onsite), but also their transfer and deposition elsewhere in the river basin and out of the catchment (off-site). The assessment of soil erosion may be performed using and analyzing measurements data (sediment discharge series and soil erosion measurements) or applying various analytical models. It is well known fact that the measurements results are available only in a few experimental catchments in most of the countries all over the World and as a consequence the researchers are frequently using the analytical models. For calculation of the Sediment yield in the S1-3 Watershed of Iran we used the IntErO model (Spalevic, 2011) based on EPM method (Gavrilovic, 1972). Calculated peak discharge from the S1-3 Watershed was $87 \mathrm{~m}^{3} \mathrm{~s}^{-1}$ for the incidence of 100 years and the net soil loss was $5,574 \mathrm{~m}^{3} \mathrm{~km}^{-2}$, specific $194 \mathrm{~m}^{3} \mathrm{~km}^{-2}$ per year. Taking into consideration the results of this study and previous experiences of the other researchers, it was concluded that the IntErO Model may be applied to the other regions similar to Shirindareh basin for calculation of sediment yield and identification of critical areas in watersheds.
\end{abstract}

Keywords: soil erosion, IntErO Model, sediment yield, ShirinDareh watershed

\section{INTRODUCTION}

Soil degradation and desertification risk is a globally acknowledged issue with ecological, socioeconomic, cultural and political implications at both the regional and local scales. Those processes occur in both developed and emerging countries and affect arid, dry and even sub-humid areas (Strijker, 2005; Koulouri and Giourga, 2007; Helming et al., 2011).

\footnotetext{
${ }^{1}$ University of Montenegro, Biotechnical Faculty, Mihaila Lalića 1, 81000 Podgorica, Montenegro

${ }^{2}$ North Khorasan Provincial FRWO, Iran

${ }^{3}$ Department of Geography, Faculty of Philosophy Niksic, University of Montenegro

*Corresponding author: velibor.spalevic@gmail.com
} 
Soil degradation caused by erosion, together with rapid population increase, are ranked as the most important environmental problems in the world (Stoffel and Huggel, 2012; Ristic et al., 2001) where the erosion is a key driver of land degradation heavily affecting sustainable land management in various environments worldwide (Ballesteros-Cánovas et al., 2015; Stoffel et al., 2013; Verheijen et al., 2009). Every year, soil erosion leads to the loss of about ten million hectares of cropland, which reduces the limited amount of arable land available for food production, thereby contributing to malnourishment in millions of people (Pimentel, 2006). In addition, the accumulation of large volumes of sediment can cause severe sedimentation in reservoirs and channel beds, resulting in the loss of various functions in these hydraulic projects. Thus, it is important to determine the sediment yield rates in watersheds, which can provide a good basis to facilitate soil erosion control and river basin management (Zhao et al., 2015).

Soil erosion is a growing problem globally and is serious problem in Iran. Quantitative information on soil loss is needed for erosion risk assessment. The modelling of the erosion process has progressed rapidly, and a variety of models have been developed to predict both runoff and soil loss. The authors of this study used the computer - graphic models (Spalevic, 2011; Spalevic, 1999a) for prediction of soil erosion intensity from the catchment area - IntErO model (Spalevic, 2011).

The objectives of the present study were: (1) to quantify the sediment yield in the studied S1-3 Watershed of the Shirindareh River Basin on the north-eastern part of Iran; (2) testing the possibility of application of the IntErO model in the conditions of the Caspian Sea Watersheds.

\section{MATERIAL AND METHODS}

The study was conducted in the area of the S1-3 watershed of the Shirindareh River Basin of the Caspian Sea Watershed (Figure 1).
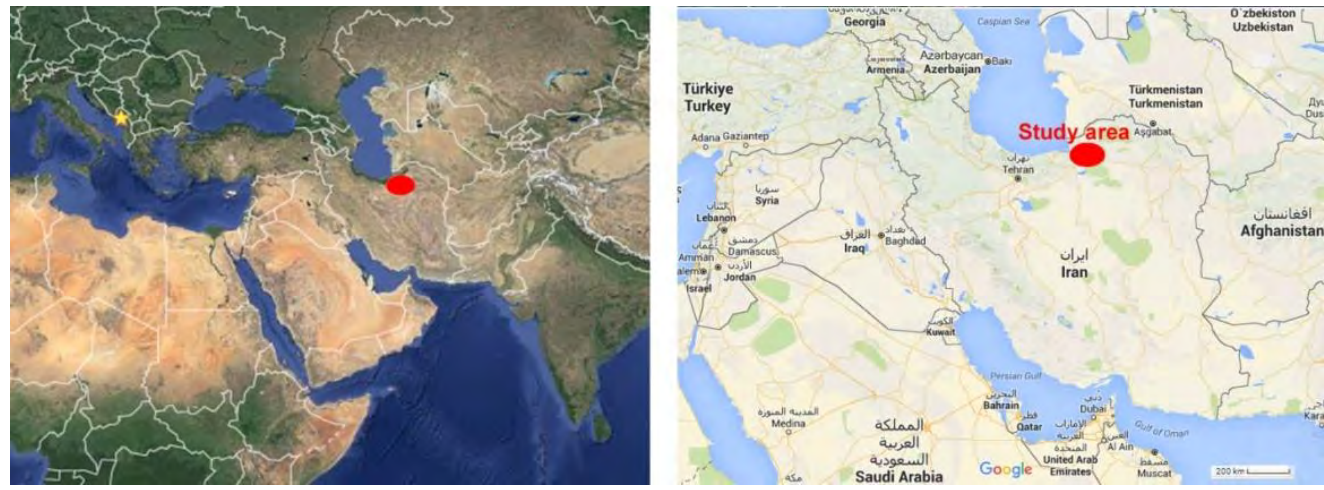

Figure 1. Study area of the S1-3 watershed, the Shirindareh River Basin, Iran 
The studied river basin of the S1-3 watershed is located in the north-eastern part of Iran and encompasses an area of $28.6 \mathrm{~km}^{2}$. In terms of geomorphology and climate, it is part of the natural entity of the Shirindareh River Basin of the Razavi Khorasan that lies between steep slopes and plains bordering with Turkmenistan on Chaat region, draining to the Caspian Sea Watershed in the Gulf of Hasan Ghuly.

Shirindareh river basin area has the important strategic values for North Khorasan province. Because of quality and quantity of surface runoff and need to supply of drinking water and agriculture a rock fill dam has been constructed on the main river. The management of upland areas is very important to increase performance of the dam (Behzadfar et al., 2015).

The shortest distance between the fountainhead and the mouth, $1 \mathrm{v}$, is $7 \mathrm{~km}$; and the total length of the main watercourse with tributaries is $47.7 \mathrm{~km}$. The average slope gradient in the river basin, Isr, is calculated on $23.50 \%$ what indicates that in the river basin prevailing steep slopes. The average river basin altitude Hsr, is calculated on $1,798 \mathrm{~m}$.
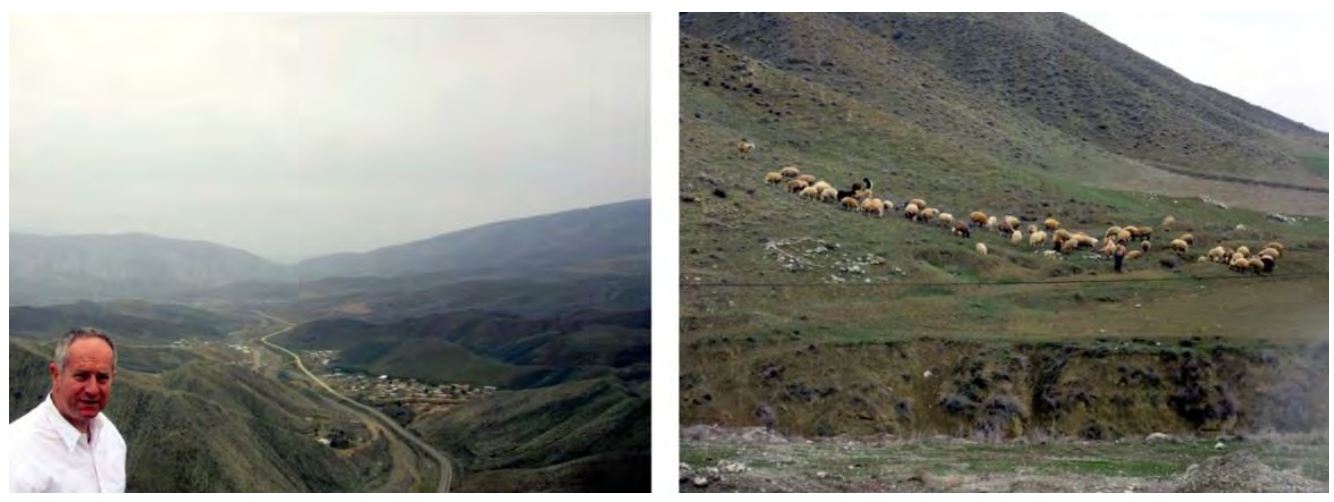

Figure 2. Details from the filed visit: Problem with overgrazing (February 2015)

Fieldwork was undertaken to collect detailed information on the intensity and the forms of the soil erosion, the status of the plant cover, the type of land use, and the measures in place contributing to the reduction or alleviation of the erosion processes. Morphometric methods were used to determine the slope, the specific lengths, the exposition and form of the slopes, the depth of the erosion base, the density of the erosion rills, the degree of the rills, and other relevant parameters. Different forms: the shape of the slope, the depth of the erosion base and the density of erosion rills were determined.

Climatological data were received from the North Khorasan Meteorological stations of Iran. Pedological survey was based on the research of the National Geological Survey 
Organization (NGS) led by Bolourchi et al. (1987), who analysed the physical and chemical properties of all geological formations of North Khorasan province, including those in the study area of the S1-3 Basin.

For the obtaining data on forecasts of peak discharge from the basin and the intensity of the soil erosion we used the program package Intensity of Erosion and Outflow - IntErO (Spalevic, 2011) that is an integrated, second-generation version of the program "Surface and Distance Measuring" (Spalević, 1999) and the program "River basins" (Spalević, 2000). The Erosion Potential Method - EPM (Gavrilovic, 1972) is embedded in the algorithm of this computer-graphic method.

The model is currently in use in all the countries of Western Balkans, but also used by some researchers from Czech Republic and Italy (Gazdic et al., 2015; Spalevic et al., 2015a, 2015b, 2015c, 2015d, 2015e, 2015f, 2015g, 2015h, 2015i, 2015k; Kostadinov et al., 2014, Curovic et al., 1999). The EPM and/or the IntErO model have been successfully used in some regions of Iran: Chamgardalan, Kasilian, Kermanshah, Razavi Khorasan (Barovic et al., 2015; Behzadfar et al., 2015; Behzadfar et al., 2014a; Behzadfar et al., 2014b; Sadeghi, 1993; Amiri, 2010).

\section{RESULTS AND DISCUSSION}

The geological structure and soil characteristics of the area. Our analysis, extracting the geological data from the Geological map of Iran (Bolourchi et al., 1987), shown that the poor water permeability rocks prevails. The geological structure of the studied river basin is presented at the Table 1.

Table 1. The geological structure of the S1-3 watershed of the Shirindareh River Basin

\begin{tabular}{llc}
\hline A part consisted of a very permeable products from rocks & $\mathrm{fp}$ & 0.07 \\
Apart of the river basin area consisted of medium permeable rocks & $\mathrm{fpp}$ & 0.42 \\
A part of the river basin consisted of poor water permeability rocks & fo & 0.51 \\
\hline
\end{tabular}

The coefficient of the region's permeability, $\mathrm{S} 1$, is calculated on 0.83 . The most common soil type in the studied area is Inceptisols with Calcic horizon.

There is a highly variable climate and human pressure on the land in the studied area of the S1-3 Watershed of the Shirindareh River Basin. The climate is continental, with cold winters and warm, dry summers. The Basic climatological data needed for calculation of Soil erosion intensity are presented at the Table 2. 
Table 2. Basic climatological data needed for calculation of Soil erosion intensity

\begin{tabular}{cr}
\hline The absolute maximum air temperature & $34.6\left[{ }^{\circ} \mathrm{C}\right]$ \\
\hline The absolute negative air temperature & $-24.4\left[{ }^{\circ} \mathrm{C}\right]$ \\
\hline The average annual air temperature $(\mathrm{t} 0)$ & $10.2\left[{ }^{\circ} \mathrm{C}\right]$ \\
\hline The average annual precipitation $\left(\mathrm{H}_{\text {year }}\right)$ & $328.4[\mathrm{~mm}]$ \\
\hline
\end{tabular}

Source: The North Khorasan Meteorological stations of Iran

The temperature coefficient of the region, $\mathrm{T}$, is calculated on 1.01; the amount of torrential rain, hb, on $36.84 \mathrm{~mm}$.

Vegetation and land use. Good vegetation cover reduces overland flow velocity and increases infiltration by protecting the soil against rain drop impact and reducing the erosive capacity of the rain (Asfaha et al., 2015; Molina et al., 2007) whereas deforestation leads to increased peak discharge (Bonan et al., 2004).The studied area is located in Middle-East of the Kope-Dagh geographical region. According to the available literature and the analysis using the Google maps and Google Earth, including the records from the field visits almost all the studied area is used for the pastures and meadows (Table 3 ).

Table 3. Land use structure at the S1-3 watershed of the Shirindareh River Basin

\begin{tabular}{lcc}
\hline A part of the river basin under forests & $\mathrm{fs}$ & 0 \\
\hline A part of the river basin under grass, meadows, pastures and orchards & $\mathrm{ft}$ & 0.98 \\
\hline A part under bare land, plough-land and ground without vegetation & $\mathrm{fg}$ & 0.02 \\
\hline
\end{tabular}

The coefficient of the river basin planning, Xa, is calculated on 0.61 . The coefficient of the vegetation cover, $\mathrm{S} 2$, is calculated on 0.8 .

Soil erosion and runoff characteristics. The dominant erosion form in this area is surface erosion. Problems with overgrazing and livestock traces are recorded also all over the studied area.

The coefficient of the river basin form, A, is calculated on 0.81 . Coefficient of the watershed development, $\mathrm{m}$, is 0.37 and average river basin width, $\mathrm{B}$, is $3.63 \mathrm{~km}$. (A)symmetry of the river basin, a, is calculated on 1.1 and that indicates that there is a possibility for large flood waves to appear in the studied river basin. The value of $G$ coefficient of 1.66 indicates there is very high density of the hydrographic network.

The height of the local erosion base of the river basin, Hleb, is $578 \mathrm{~m}$. Coefficient of the erosion energy of the river basin's relief, Er, is calculated on 79.5. According to the erosion type, the dominant process is surface erosion. 
The value of $Z$ coefficient of 0.748 indicates that the river basin belongs to II destruction category. The strength of the erosion process is high, and according to the erosion type, it is intrusive erosion. We calculated the soil losses from the S1-3 catchment on 5574 $\mathrm{m}^{3} \mathrm{yr}^{-1}$ and the peak discharge on $87 \mathrm{~m}^{3} \mathrm{~s}^{-1}$ (for the incidence of 100 years).

Processing the input data using the IntErO model we received the results in relation to the sediment yield for the S1-3 Watershed of the Shirindareh River Basin of Iran (Table 4).

Table 4. Part of the IntErO report for the S1-3 Watershed River Basin

\begin{tabular}{|c|c|c|c|}
\hline Input data & & & \\
\hline River basin area & $\mathrm{F}$ & 28.68 & $\mathrm{~km}^{2}$ \\
\hline The length of the watershed & $\mathrm{O}$ & 29.16 & $\mathrm{~km}$ \\
\hline Natural length of the main watercourse & $\mathrm{Lv}$ & 7.03 & $\mathrm{~km}$ \\
\hline The shortest distance between the fountainhead and mouth & $\mathrm{Lm}$ & 6.43 & $\mathrm{~km}$ \\
\hline The total length of main watercourse with tributaries of I \& II class & $\Sigma \mathrm{L}$ & 47.7 & $\mathrm{~km}$ \\
\hline River basin length measured by a series of parallel lines & $\mathrm{Lb}$ & 7.91 & $\mathrm{~km}$ \\
\hline The area of the bigger river basin part & Fv & 22.22 & $\mathrm{~km}^{2}$ \\
\hline The area of the smaller river basin part & Fm & 6.46 & $\mathrm{~km}^{2}$ \\
\hline Altitude of the first contour line & h0 & 1700 & $\mathrm{~m}$ \\
\hline The lowest river basin elevation & Hmin & 1611 & $\mathrm{~m}$ \\
\hline The highest river basin elevation & Hmax & 2189 & $\mathrm{~m}$ \\
\hline The volume of the torrent rain & $\mathrm{hb}$ & 36.84 & $\mathrm{~mm}$ \\
\hline Incidence & $\mathrm{Up}$ & 100 & years \\
\hline Average annual air temperature & t0 & 9.3 & ${ }^{\circ} \mathrm{C}$ \\
\hline Average annual precipitation & Hyr & 343 & $\mathrm{~mm}$ \\
\hline Types of soil products and related types & $\mathrm{Y}$ & 1.1 & \\
\hline River basin planning, coefficient of the river basin planning & $\mathrm{Xa}$ & 0.61 & \\
\hline
\end{tabular}

\begin{tabular}{llc}
\hline \multicolumn{1}{c}{ Results } & & \\
\hline \hline Numeral equivalents of visible and clearly exposed erosion process & $\varphi$ & 0.64 \\
\hline Coefficient of the river basin form & A & 0.81 \\
\hline Coefficient of the watershed development & m & 0.37 \\
\hline Average river basin width & B & $3.63 \mathrm{~km}$ \\
\hline (A)symmetry of the river basin & a & 1.1 \\
\hline Density of the river network of the basin & G & 1.66 \\
\hline
\end{tabular}




\begin{tabular}{|c|c|c|c|}
\hline Results & & & \\
\hline Coefficient of the river basin tortuousness & $\mathrm{K}$ & 1.09 & \\
\hline Average river basin altitude & $\mathrm{Hsr}$ & 1798.79 & $\mathrm{~m}$ \\
\hline Average elevation difference of the river basin & $\mathrm{D}$ & 187.79 & $\mathrm{~m}$ \\
\hline Average river basin decline & Isr & 23.5 & $\%$ \\
\hline The height of the local erosion base of the river basin & Hleb & 578 & $\mathrm{~m}$ \\
\hline Coefficient of the erosion energy of the river basin's relief & $\mathrm{Er}$ & 79.5 & \\
\hline Coefficient of the region's permeability & S1 & 0.83 & \\
\hline Coefficient of the vegetation cover & $\mathrm{S} 2$ & 0.8 & \\
\hline Analytical presentation of the water retention in inflow & $\mathrm{W}$ & 0.4934 & $\mathrm{~m}$ \\
\hline Energetic potential of water flow during torrent rains & $2 \mathrm{gDF}^{\wedge 1 / 2}$ & 325.07 & $\mathrm{~m} \mathrm{~km} \mathrm{~s}$ \\
\hline Maximal outflow from the river basin & Qmax & 86.79 & $\mathrm{~m}^{3} \mathrm{~s}^{-1}$ \\
\hline Temperature coefficient of the region & $\mathrm{T}$ & 1.01 & \\
\hline Coefficient of the river basin erosion & $\mathrm{Z}$ & 0.748 & \\
\hline Production of erosion material in the river basin & Wyr & 20284.32 & $\mathrm{~m}^{3} \mathrm{yr}^{-1}$ \\
\hline Coefficient of the deposit retention & $\mathrm{Ru}$ & 0.275 & \\
\hline Real soil losses & Gyr & 5574.57 & $\mathrm{~m}^{3} \mathrm{yr}^{-1}$ \\
\hline Real soil losses per km2 & $\mathrm{Gyr} \mathrm{km}^{2}$ & 194.37 & $\mathrm{~m}^{3} \mathrm{~km}^{2} \mathrm{yr}^{-1}$ \\
\hline
\end{tabular}

\section{CONCLUSIONS}

The study was conducted in the area of the S1-3 Basin of Shirindareh region, the main tributary of the river Atrakin Iran. Many factors have influenced the development of erosion processes in the studied territory. The most significant factors are the area's climate, relief, geological substrate and pedological composition, as well as the condition of the vegetation cover and the land use.

We calculated the soil erosion intensity and runoff using the IntErO model. According to our findings, it can be concluded that there is a possibility for large flood waves to appear in the studied S1-3 river basin.

Calculated peak discharge was $87 \mathrm{~m}^{3} \mathrm{~s}^{-1}$ for a return period of 100 years. The value of $Z$ coefficient of 0.748 indicates that the river basin belongs to the second destruction category out of five. The calculated net soil loss from the river basin was $5574 \mathrm{~m}^{3}$ per year, specific $194 \mathrm{~m}^{3} \mathrm{~km}^{-2}$ per year.

This study further confirmed the findings of Barovic et al., 2015; Behzadfar et al., 2015, 2014a, 2014b; Amini et al., 2014; Moradi et al., 2015; as well as Amiri, 2010; Khaleghi, 2005; Maleki, 2003; Nadjafi, 2003; Sadeghi 1993 in possibility of implementing the 
Erosion Potential Method in Iran. That leads to the conclusion that the IntErO model may be a useful tool for researchers in calculation of runoff and sediment yield for the river basins of the Caspian Sea Watershed with the similar physical-geographical characteristics like the Shirindareh River Basins. The team of authors have the same good experience about the simplicity in operation and practicality in use of the IntErO also in Saudi Arabia (Al-Turki et al., 2015) and in the Western Balkans (Barovic \& Spalevic, 2015; Vujacic \& Spalevic, 2015; Spalevic et al., 2014a, 2014b, 2014c, 2014d, 2013a, 2013b, 2013c, 2013d, 2013e, 2003a, 2003b, 1999b, 1999c).

Because of high erosion rate, complex measures must be taken for soil conservation and environmental protection in the studied area. That is key requirement for better socioeconomic growth in the future.

\section{REFERENCES}

Ali M. Al-Turki, A.M., Ibrahim, H.M., Spalevic, V., 2015. Impact of land use changes on soil erosion intensity in Wadi Jazan watershed in southwestern Saudi Arabia. Agrosym 2015, Jahorina, Bosnia and Herzegovina; 10/2015

Amiri, F., 2010. Estimate of Erosion and Sedimentation in Semi-arid Basin using Empirical Models of Erosion Potential within a Geographic Information System. Air, Soil and Water Research, 3: 37-44.

Asfaha, T. G. Frankl, A. Haile, M., Zenebe, A., Nyssen, J. 2015. Determinants of peak discharge in steep mountain catchments - Case of the Rift Valley escarpment of Northern Ethiopia. Journal of Hydrology. In press.

Ballesteros-Cánovas, J.A., Czajka, B., Janecka, K., Lempa, M., Kaczka, R.J., Stoffel, M. 2015. Flash floods in the Tatra Mountain streams: Frequency and triggers. Science of the Total Environment 511: 639-648.

Barovic, G. and Spalevic, V. 2015. Calculation of runoff and soil erosion intensity in the Rakljanska Rijeka Watershed, Polimlje, Montenegro. The 6th International Symposium Agrosym 2015, Jahorina, 15-18 October 2015, Bosnia and Herzegovina.

Barovic, G., Leandro Naves Silva, M., Veloso Gomes Batista, P., Vujacic, D., Soares Souza, W., Cesar Avanzi, J., Behzadfar M., Spalevic, V. 2015. Estimation of sediment yield using the IntErO model in the S1-5 Watershed of the Shirindareh River Basin, Iran. Agriculture and Forestry 61(3): 233-243

Behzadfar, M. Tazioli, A., Vukelic-Shutoska, M., Simunic, I., and Spalevic, V. 2014b. Calculation of sediment yield in the S1-1 Watershed, Shirindareh Watershed, Iran. Agriculture and Forestry, 60 (4): 207-216.

Behzadfar, M., Curovic, M., Simunic, I., Tanaskovik, V., Spalevic, V. 2015. Calculation of soil erosion intensity in the S5-2 Watershed of the Shirindareh River Basin, Iran. International Conference on Soil, Tirana, Albania; 4-7 May, 2015. 
Behzadfar, M., Djurovic, N., Simunic, I., Filipovic, M. and Spalevic, V. 2014a. Calculation of soil erosion intensity in the S1-6 Watershed of the Shirindareh River Basin, Iran. International Scientific conference: Challenges in modern agricultural production, December 11, 2014, Skopje, Macedonia.

Curovic, M., Spalevic, V., Dozic, S., Dubak, D. 1999. Proposal of Anti Erosion Regulation of Department 17 of Husbandry Unit Rudo Polje-Kovren. Agriculture and Forestry, 45 (3-4): 5-23.

Gavrilovic, S. 1972. Engineering of torrential flows and erosion. Izgradnja. Beograd.

Gazdic, M., Pejovic, S., Vila, D., Vujacic, D., Barovic, G., Djurovic, N., Tanaskovikj, V., and Spalevic, V. 2015. Soil erosion in the Orahovacka Rijeka Watershed, Montenegro. The 6th International Symposium Agrosym 2015, Jahorina, 15-18 October 2015, Bosnia and Herzegovina.

Helming, K., Diehl, T., Kuhlman, T., Jansson, P.H., Verburg, M., Bakker, M., PerezSoba, L. 2011. Ex ante Impact Assessment of Policies Affecting Land Use, Part B: Application of the Analytical Framework. Ecology and Society 16 (1): 29-38.

Kostadinov, S., Zlatic, M., Dragicevic, S., Novkovic, I., Kosanin, O., Borisavljevic, A., Lakicevic, M., Mladjan, D., 2014. Anthropogenic influence on erosion intensity changes in the Rasina river watershed - Central Serbia.

Koulouri, M., and C. Giourga. 2007. Land Abandonment and Slope Gradient as Key Factors of Soil Erosion in Mediterranean Terraced Lands. Catena 69: 274-281.

Pimentel, D., 2006. Soil erosion: a food and environmental threat. Environ. Dev. Sustain. 8, 119-137.

Ristic, R., Kostadinov, S., Malosevic, D., Spalevic, V. 2001. Erosion aspect in the assessment of soils of hydrologic classes and determination of $\mathrm{CN}$ number of runoff curve. Acta biologica Iugoslavica - serija A: Zemljište i biljka. 2001, vol. 50, No 3, p.165-174.

Sadeghi, H. 1993. Comparison of some erosion potential and sediment yield assessment models in Ozon-Dareh sub-catchment. Proceedings of the National Conference on Land Use Planning, Tehran, Iran, pp. 41-75.

Spalevic, V. 1999a. Application of computer-graphic methods in the studies of draining out and intensities of ground erosion in the Berane valley. Master thesis. Faculty of Agriculture of the University of Belgrade, Serbia (in Serbian). pp-131.

Spalevic, V. 2011. Impact of land use on runoff and soil erosion in Polimlje. Doctoral thesis, Faculty of Agriculture of the University of Belgrade, Serbia, p 1-260.

Spalevic, V. Curovic, M. Tanaskovic, V., Djurovic, N., Lenaerts, T. and Nyssen, J. 2015k. Application of the IntErO model for the assessment of the soil erosion intensity and runoff of the river basin Dragovo Vrelo, Montenegro (invited speaker). Balkan Agriculture Congress, 8-10 September 2014. Edirne, Turkey. 
Spalevic, V., Barovic, G., Mitrovic, M., Hodzic, R., Mihajlovic, G., Frankl, A. 2015g. Assessment of sediment yield using the Erosion Potential Method (EPM) in the Karlicica Watershed of Montenegro. International Conference on Soil, Tirana, Albania; 4-7 May, 2015.

Spalevic, V., Barovic, G., Vujacic, D., Bozovic, P., Kalac, I., Nyssen, J. $2015 f$. Assessment of soil erosion in the Susica River Basin, Berane Valley, Montenegro. International Conference on Soil, Tirana, Albania; 4-7 May, 2015.

Spalevic, V., Blinkov, I., Trendafilov, A., Mukaetov, D., Djekovic, V., Djurovic, N. 2015h. Soil erosion assessment using the EPM method: A case study of the Ramcina River Basin, Montenegro. International Conference on Soil, Tirana, Albania; 4-7 May, 2015.

Spalevic, V., Curovic, M. Tanaskovik, V., Oljaca, M., Djurovic, N. 2013b. The impact of land use on soil erosion and run-off in the Krivaja river basin in Montenegro. The First International Symposium on Agricultural Engineering, 4th - 6th October 2013, Belgrade-Zemun, Serbia, VI: 1-14.

Spalevic, V., Curovic, M., Andjelkovic, A., Djekovic, V., Ilci, S. 2014a. Calculation of soil erosion intensity in the Nedakusi Watershed of the Polimlje Region, Montenegro. International Scientific conference: Challenges in modern agricultural production, December 11, 2014, Skopje, Macedonia.

Spalevic, V., Curovic, M., Barovic, G., Florijancic, T., Boskovic, I., Kisic, I. 2015a. Assessment of Sediment Yield in the Tronosa River Basin of Montenegro. The 9th International Symposium on Plant-Soil Interactions at Low pH. October 18-23, 2015, Dubrovnik, Croatia.

Spalevic, V., Curovic, M., Barovic, G., Vujacic, D., Djurovic, N. 2015e. Soil erosion in the River Basin of Kisjele Vode, Montenegro. International conference: Land Quality and Landscape Processes, Keszthely, Hungary; 06/2015

Spalevic, V., Curovic, M., Barovic, G., Vujacic, D., Tunguz, V., Djurovic, N. 2015b. Soil erosion in the River Basin of Provala, Montenegro. Agrosym 2015, Jahorina, Bosnia and Herzegovina; 10/2015.

Spalevic, V., Curovic, M., Billi, P., Fazzini, M. Frankl, A., and Nyssen, J. 2014d. Soil erosion in the Zim Potok Watershed, Polimlje River Basin, Montenegro. The 5th International Symposium Agrosym 2014, Jahorina, October 2014, Bosnia and Herzegovina, p 739-747.

Spalevic, V., Curovic, M., Povilaitis, A., Radusinovic, S. 2003a. Estimate of Maximum Outflow and Soil Erosion in the Biogradska River Basin. Monographs No1, p. 1 20. Biodiversity of the Biogradska Gora National Park; Editors: Pesic, V., Karaman, G., Spalevic, V., Jovovic, Z., Langurov, M. Department of Biology, University of Montenegro, Podogirca. 
Spalevic, V., Curovic, M., Tanaskovik, V., Pivic, R., Djurovic, N. 2013e. Estimation of soil erosion intensity and runoff in the river basin of Bijeli Potok, Northeast of Montenegro. In proceeding of the 1st International Congress on Soil Science, XIII Congress of Serbian Soil Science Society "SOIL - WATER - PLANT", October, 2013. Belgrade, Serbia.

Spalevic, V., Curovic, M., Uzen, N., Simunic, I., Vukelic-Shutoska, M. 2013d. Calculation of soil erosion intensity and runoff in the river basin of Ljesnica, Northeast of Montenegro. In proceeding of the 24th International Scientific-Expert Conference on Agriculture and Food Industry, Sarajevo, Bosnia and Herzegovina.

Spalevic, V., Curovic, M., Vujacic, D., Barovic, G., Frankl, A., and Nyssen, J. $2015 i$. Assessment of soil erosion at the Brzava small watershed of Montenegro using the IntErO model. Geophysical Research Abstracts. Vol. 17, EGU2015-15007, 2015. EGU General Assembly 2015

Spalevic, V., Djurovic, N., Mijovic, S., Vukelic-Sutoska, M., Curovic, M. 2013a. Soil Erosion Intensity and Runoff on the Djuricka River Basin (North of Montenegro). Malaysian Journal of Soil Science, Vol. 17: p.49-68.

Spalevic, V., Dlabac, A., Jovovic, Z., Rakocevic, J, Radunovic, M., Spalevic, B., Fustic, B. 1999b. The Surface and distance Measuring Program. Acta Agriculture Serbica, Vol IV, 8, p.63-71.

Spalevic, V., Dubak, D, Fustic, B, Jovovic, Z, Ristic, R. 1999c. The Estimate of the Maximum Outflow and Soil Erosion Intensity in the Kaludra River Basin. Acta Agriculture Serbica, Vol.IV, 8, p.79-89.

Spalevic, V., Frankl, A., Nyssen, J. Curovic, M. and Djurovic, N. 2015d. Calculation of soil erosion intensity in the Sutivanska Rijeka Watershed of Montenegro using the IntErO model. 2nd International Symposium for Agriculture and Food - ISAF 2015, Faculty of Agricultural Sciences and Food - Skopje, 7-9 October, 2015, Ohrid, Macedonia.

Spalevic, V., Hübl, J. Hasenauer, H. and Curovic, M. 2014c. Calculation of soil erosion intensity in the Bosnjak Watershed, Polimlje River Basin, Montenegro. The 5th International Symposium Agrosym 201”, Jahorina, October 2014, Bosnia and Herzegovina, p 730-738.

Spalevic, V., Nyssen, J., Curovic, M., Lenaerts, T., Kerckhof, A., Annys, K. Van Den Branden, J., Frankl, A. 2013c. The impact of land use on soil erosion in the river basin Boljanska Rijeka in Montenegro. In proceeding of the 4th International Symposium “Agrosym 2013” (3-6 October, 2013, Jahorina, Bosnia). Key note speakers, p. 54-63.

Spalevic, V., Seker, G, Fuštić, B, Šekularac, Ristić G. 2003b. Conditions of Erosion of Soil in the Drainage Basin of the Crepulja - Lucka River: p. 287-292. International 
conference, "Natural and Socioeconomic effects of Erosion Control in Mountainous Regions", Banja Vrujci, Faculty of Forestry, Belgrade University, World Association of S\&W Conservation.

Spalevic, V., Tazioli, A. Djekovic, V., Andjelkovic, A., and Djurovic, N. 2014b. Assessment of soil erosion in the Lipnica Watershed, Polimlje, Montenegro. The 5th International Symposium “Agrosym 2014”, Jahorina, 23-26 October 2014, Bosnia and Herzegovina, p 723-729.

Spalevic, V., Vujacic, D., Barovic, G., Simunic, I., Moteva, M. and Tanaskovik, V. 2015c. Soil erosion evaluation in the Rastocki Potok Watershed of Montenegro using the Erosion Potential Method. 2nd International Symposium for Agriculture and Food - ISAF 2015, Faculty of Agricultural Sciences and Food - Skopje, 7-9 October, 2015, Ohrid, Macedonia.

Stoffel, M., Corona, C., Ballesteros-Cánovas, J.A., Bodoque, J.M. 2013. Dating and quantification of erosion processes based on exposed roots. Earth-Science Reviews, 123:18-34.

Stoffel, M., Huggel, C., 2012. Effects of climate change on mass movements in mountain environments. Progress in Physical Geography 36, 421-439.

Strijker, D. 2005. Marginal Lands in EuropeCauses of Decline. Basic and Applied Ecology 6: 99-106.

Verheijen, F.G.A., Jones, R.J.A., Rickson, R.J., Smith, C.J., 2009. Tolerable versus actual soil erosion rates in Europe. Earth-Science Reviews 94, 23-38.

Vujacic, D and Spalevic, V. 2015. Assessment of runoff and soil erosion in the Radulicka Rijeka Watershed, Polimlje, Montenegro. The 6th International Symposium Agrosym 2015, Jahorina, 15-18 October 2015, Bosnia and Herzegovina.

Zhao, G., Klik, A., Mua, X., Wang, F., Gao, P., Sun, W. 2015. Sediment yield estimation in a small watershed on the northern Loess Plateau, China. Geomorphology 241: 343-352. 